\title{
Assessment of Predictors for Early Resistance to Hepatitis C Virus Treatment
}

\author{
Noha El-Mashad', Hekmat El Tantawy², Eman Elsayed', Sherein Rkha', Maha Maher3, \\ Mohammed Shokhba ${ }^{2}$ \\ ${ }^{1}$ Department of Clinical Pathology, Faculty of Medicine, Mansoura University, Mansoura, Egypt \\ ${ }^{2}$ Department of Zoology, Faculty of Science, Suez Canal University, Ismailia, Egypt \\ ${ }^{3}$ Department of Internal Medicine, Specialized Medical Hospital, Faculty of Medicine, Mansoura University, \\ Mansoura, Egypt \\ Email: renadodi@yahoo.com
}

Received 4 March 2015; accepted 27 June 2015; published 30 June 2015

Copyright (C) 2015 by authors and Scientific Research Publishing Inc.

This work is licensed under the Creative Commons Attribution International License (CC BY).

http://creativecommons.org/licenses/by/4.0/

(c) (i) Open Access

\section{Abstract}

The current standard of treatment for HCV is the combination of pegylated interferon (PEG-IFN) and ribavirin (RBV). Response to therapy is influenced by different factors related to virus or host characteristics. In this study we detected $\mathrm{HCV}$ genotype in some patients with chronic HCV infection-who received interferon plus ribavirin therapy and evaluating some risk factors in early resistance to treatment. These risk factors included age, gender, ALT\& AST levels, HCV viral load \& genotype. This study included 60 patients with chronic HCV infection and subjected to PEG-INF plus RBV therapy. 40 (gp I) had developed resistance after 12 weeks; while group II are the responders. on comparing patients in group I $n=40$ (who developed resistance) to patients in group 2, no $=20$ (responders), it has been found that the most important risk factors for developing resistance are the increased viral load of HCV-RNA, and AST.HCV-genotype as a risk factor was significantly higher among cases with genotype 1 and 4 and $P$ value was 0.004 . This was followed by ALT and AFP as risk factors with $P$ value 0.004 for each and age with $P$ value 0.026 . However, regarding sex of the patients there was no significant difference between group I and II. In conclusion: the most frequent HCV genotype in resistant group were genotype I and IV, while in responder patient were genotype $2 \& 3$. The most important risk factor in this study is viral load and HCV genotype.

\section{Keywords}

HCV, Ribavirin, Pegylated Interferon, Resistance 


\section{Introduction}

The primary goal of treatment is to eradicate (that is/cure) HCV infection [1]. But therapy can also decrease hepatic inflammation and fibrosis, slow disease progression and reduce the risks for cirrhosis and hepatocellular carcinoma even in absence of cure [2].

The current standard of treatment is the combination of pegylated interferon (PEG-IFN) and ribavirin (RBV) [3]. The efficacy endpoint of hepatitis $C$ treatment is the "sustained virological response" (SVR), which is defined by the absence of detectable HCV RNA in serum as assessed by an HCV RNA assay with a lower limit of detection of $50 \mathrm{IU} / \mathrm{ML}$ or less, $24 \mathrm{wk}$ after the end of treatment [4].

There are patients who do not achieve a SVR due to unresponsiveness or relapse after treatment, as well as those who lake tolerance to adverse events that occur during treatment. Therefore, the shorter treatment duration is, the more convenient routes of administration and favorable side-effect profiles are [5].

Response to therapy is influenced by different factors related to virus or host characteristics [6].

So, our aim in this work is to detect HCV genotype in some patients with chronic HCV infection-who receive interferon plus ribavirin therapy and evaluate predictors of early resistance to treatment.

\section{Patients and Methods}

60 patients were selected for this study infected with HCV and investigated to the treatment of PEG-interferon plus ribavirin. HCV-RNA detected by quantitative real time PCR was performed routinely before treatment and 12 weeks after starting treatment course.

\subsection{Patients Were Divided into 2 Groups}

First group: included 40 patients who are non responders to PEG-IFN plus RBV for 12 weeks. Quantitative PCR testing had been performed and proved to be positive.

Second group: is the responders group which included 20 patients who have responded to PEG-IFN plus RBV therapy. Quantitative PCR proved to be negative, six months after completion of treatment course.

All samples were collected after obtaining formal consent from the patients.

\subsection{Sample Collection}

$5 \mathrm{ml}$ of venous blood was collected from each case under complete aseptic technique and divided into serum and whole blood on EDTA(for platelet count).Serum samples used for HCV genotyping were stored at $-20^{\circ} \mathrm{C}$.

\subsection{Laboratory Procedures}

Biochemical investigation included ALT and AST levels were determined using automatic autoanalyser, Cobas Amplicor System.

Hematological investigations. Hemoglobin $(\mathrm{Hb})$ measurement and platelets count of the studied samples were performed by automatic system (sysmex).

Determination of degree of fibrosis $(F)$ and degree of activity $(A)$ for a liver biopsy. The activity (A) of the disease which was classified into A0, A1, A2 and A3while degree of fibrosis (F) was classified to F0, F1, F2, F3 and F4 according to the METAVIR classification system [7] [8].

Hepatic activity score (A)

- $\mathrm{A} 0=$ no activity (no or minimal inflammation).

- $\mathrm{A} 1=$ mild activity.

- $\mathrm{A} 2$ = moderate activity.

- $\mathrm{A} 3$ = severe activity.

Hepatic fibrosis score (F)

- $\mathrm{F} 0=$ no fibrosis (normal liver).

- $\mathrm{F} 1=$ mild fibrosis (portal fibrosis).

- $\mathrm{F} 2=$ moderate fibrosis (few septa).

- $\mathrm{F} 3=$ severe fibrosis (numerous septa).

- $\mathrm{F} 4=$ cirrhosis. 
HCV genotyping (this includes viral RNA extraction, RNA purification and cDNA synthesis and amplification).

Viral RNA extraction and purification from the serum samples of patients using a commercial specific kit, Qiaamp viral RNA kit, (QIAGEN GmbH, Germany (www.qiagen.com).

Viral RNA is suspended in $60 \mathrm{ul}$ of buffer AVE equilibrated at room temperature.

cDNA synthesis and amplification: were performed according to manufacturer instructions using commercial Verso 1-Step QRT-PCR ROX KitProvided byThermo FisherScientific (ABgene). ABgene UK.

Abgene.techsupport@thermofisher.com. (www.abgene.com).

The sequence of external and internal PCR primers: Specific for 5'-UTR region of HCV genome [9] were as follow:

ExF; 5'-AGCGTCTAGCCATGGCGT-3'

ExR; 5'-GCACGGTCTACGAGACCT-3'

InF; 5'-GTGTCTGCGGAACCGG-3'

InR; 5'-GGGCACTCGCAAGCACCC-3'

-The volume of each component in the reaction mix

\begin{tabular}{cc}
\hline & Volume \\
\hline Verso Enzyme Mix & $0.25 \mu \mathrm{l}$ \\
1-Step QPCR Mix & $12.5 \mu \mathrm{l}$ \\
RT Enhancer & $1.25 \mu \mathrm{l}$ \\
External Forward Primer (1:10) & $0.5 \mu \mathrm{l}$ \\
External Reverse Primer (1:10) & $0.5 \mu \mathrm{l}$ \\
PCR Water & $5.0 \mu \mathrm{l}$ \\
Template (RNA) & $5.0 \mu \mathrm{l}$ \\
\hline
\end{tabular}

\section{-QRT-PCR thermal cycling program consist of}

\begin{tabular}{cccc}
\hline & Temp. & Time & Number of cycle \\
\hline cDNA Synthesis & $50^{\circ} \mathrm{C}$ & $15 \mathrm{~min}$ & 1 Cycle \\
Thermo-Start Activation & $95^{\circ} \mathrm{C}$ & $15 \mathrm{~min}$ & 1 Cycle \\
Denaturation & $95^{\circ} \mathrm{C}$ & $15 \mathrm{sec}$ & \\
Annealing & $50^{\circ} \mathrm{C}-60^{\circ} \mathrm{C}$ & $30 \mathrm{sec}$ & 40 Cycles \\
Extension & $72^{\circ} \mathrm{C}$ & $30 \mathrm{sec}$ & \\
\hline
\end{tabular}

Nested-PCR intended to reduce the contamination in products. This involves two sets of primers, used in two successive runs of polymerase chain reaction, the second set intended to amplify a secondary target within the first run product [9].

$3 \mu \mathrm{l}$ of the first round PCR product was used as template and $0.5 \mu \mathrm{l}$ of each diluted (1:10) internal primer was added to the reaction. Other PCR components were similar to the first round as follow:

-The volume of each component in the reaction mix

\begin{tabular}{cc}
\hline & Volume \\
\hline Verso Enzyme Mix & $0.25 \mu \mathrm{l}$ \\
1-Step QPCR Mix & $12.5 \mu \mathrm{l}$ \\
RT Enhancer & $1.25 \mu \mathrm{l}$ \\
Internal Forward Primer (1:10) & $0.5 \mu \mathrm{l}$ \\
Internal Reverse Primer (1:10) & $0.5 \mu \mathrm{l}$ \\
PCR Water & $5.0 \mu \mathrm{l}$ \\
Template (cDNA) & $3.0 \mu \mathrm{l}$ \\
\hline
\end{tabular}


Apart from annealing temperature which was $64^{\circ} \mathrm{C}$ for 40 seconds, other steps of nested-PCR program were similar to the first round.

\subsection{RFLP Performed for HCV Required}

I-Two pairs of restriction enzymes, Hinf I/ScrF I, Hinf I/MvaI and Bsh1236 I, were used and provided by Fermentas life sciences, (www.fermentas.com).

$$
\begin{aligned}
& \text { 1-HinfI } \\
& \text {-Cuts at } \quad 5^{\prime} \ldots \mathrm{G} \downarrow \mathrm{A} \quad \mathrm{T} \quad \mathrm{C} \ldots 3^{\prime} \\
& \text { 3'...C T A } \mathrm{A} \uparrow \text { G...5' } \\
& 3^{\prime} \ldots \mathrm{G} \mathrm{G} \uparrow \mathrm{C} \text { C...5' } \\
& \text { 3'...G G } \uparrow C \text { C...5' }
\end{aligned}
$$

II-1 $\mathrm{ml}$ of 10X Fast Digest Buffer: are an advanced line of restriction enzymes for rapid DNA digestion within 5 - 15 minutes.

Pohjanpelto et al. [9] divided each nested-PCR products into 3 - $1.5 \mathrm{ml}$ microtubes and the restriction enzymes were added to the assigned tube as follow:

\section{- Protocol for Fast Digestion of PCR product}

\begin{tabular}{cccc}
\hline & Microtube A & Microtube B & Microtube C \\
\hline PCR Water & $8.5 \mu \mathrm{l}$ & $8.5 \mu \mathrm{l}$ & $8.5 \mu \mathrm{l}$ \\
10X Fast Digest Buffer & $1.0 \mu \mathrm{l}$ & $1.0 \mu \mathrm{l}$ & $1.0 \mu \mathrm{l}$ \\
DNA & $4.0 \mu \mathrm{l}$ & $4.0 \mu \mathrm{l}$ & $4.0 \mu \mathrm{l}$ \\
HinfI & $1.0 \mu \mathrm{l}$ & $1.0 \mu \mathrm{l}$ & \\
ScrFI & $1.0 \mu \mathrm{l}$ & & \\
MvaI & & $1.0 \mu \mathrm{l}$ & $2.0 \mu \mathrm{l}$ \\
Bsh1236I & & & \\
\hline
\end{tabular}

Sample loading. In each of the three Microtubes (representing one sample) containing DNA \& restriction enzymes, $3.0 \mu \mathrm{l}$ of loading dye was added and Running them on $\mathbf{2 \%}$ agrose gel: The wells in the gel was loaded with $10.0 \mu \mathrm{l}$ of $50 \mathrm{bp}$ ladder DNA as well as $10.0 \mu \mathrm{l}$ of the restriction digest from each Microtube (each microtube represented by a well).

\subsection{Determination of HCV Genotypes}

The HCV genotypes were determined in all patients based on PCR-RFLP method. Table 1 shows RFLP pattern of HCV genotypes after digestion of PCR products with restriction enzymes [9].

\section{Results}

Table 2 shows age and gender distribution among studied groups. Non responders groups (group I) were 4 (10\%) patients below 40 years and 36 (90\%) above 40 years, while group II was represented by 10 (50\%) patients below 40 years and 10 (50\%) patients above 40 years. According to sex, non responders group were 28 (70\%) males and 12 (30\%) females, while group II was represented by (70\%) males and (30\%) females.

Table 3 shows the comparison between laboratory tests profiles in group I $(n=40)$ before and after treatment. 
Table 1. RFLP pattern of HCV genotyoes after digestion of PCR products with restriction enzymes.

\begin{tabular}{|c|c|c|c|}
\hline \multirow{2}{*}{ HCV Genotypes } & \multicolumn{3}{|c|}{ Size of Fragments } \\
\hline & Tube A (ScrF I and Hinf I) & Tube B (Mva I and Hinf I) & Tube C (Bsh1236 I) \\
\hline $1 \mathrm{a}$ & 97 bp & 97 bp & 129 bp \\
\hline $1 \mathrm{~b}$ & 97 bp & 97 bp & 99 bp \\
\hline $2 \mathrm{a}$ & $97 \mathrm{bp}$ & 174 bp & 174 bp \\
\hline $2 b$ & 174 bp & 174 bp & 174 bp \\
\hline 3a & 129 bp & 145 bp & 99 bp \\
\hline $3 b$ & 97 bp & 145 bp & 99 bp \\
\hline 4 & 97 bp & 145 bp & 129 bp \\
\hline 5 & $97 \mathrm{bp}$ & 174 bp & 99 bp \\
\hline 6 & 97 bp & 97 bp & 174 bp \\
\hline
\end{tabular}

Table 2. Age and gender distribution among studied groups.

\begin{tabular}{|c|c|c|c|c|}
\hline & & & Group I $(n=40)$ & Group II $(n=20)$ \\
\hline \multirow{6}{*}{ Age } & \multirow{3}{*}{$40<$} & No & 4 & 10 \\
\hline & & & & \\
\hline & & $\%$ & 10 & 50 \\
\hline & \multirow{3}{*}{$>40$} & $\mathrm{No}$ & 36 & 10 \\
\hline & & 10 & 30 & 10 \\
\hline & & $\%$ & 90 & 50 \\
\hline \multirow{6}{*}{ Gender } & \multirow{2}{*}{ Male } & No & 28 & 14 \\
\hline & & $\%$ & 70 & 70 \\
\hline & & & & \\
\hline & \multirow{3}{*}{ Female } & No & 12 & 6 \\
\hline & & & & \\
\hline & & $\%$ & 30 & 30 \\
\hline
\end{tabular}

Table 3. Comparison between laboratory tests profiles in group I $(n=20)$ before and after treatment of chronic HCV infection.

\begin{tabular}{|c|c|c|c|c|c|}
\hline \multicolumn{6}{|c|}{ Group I (n = 40) } \\
\hline \multirow{2}{*}{ Parameters } & Before Treatment & After Treatment & Mean Change & \multirow{2}{*}{$\begin{array}{c}\mathrm{T} \\
\text { Value }\end{array}$} & \multirow{2}{*}{$\begin{array}{c}\mathrm{P} \\
\text { Value }\end{array}$} \\
\hline & Mean \pm SD & Mean \pm SD & Mean \pm SD & & \\
\hline PCR & $2,640,634 \pm 2,354,683$ & $683,174 \pm 105,9010$ & $1,957,459 \pm 2,001,836$ & 4.37 & 0.000 \\
\hline ALT & $64.60 \pm 11.53$ & $79.95 \pm 11.38$ & $-15.35 \pm 6.68$ & -10.27 & 0.000 \\
\hline AST & $73.75 \pm 12.80$ & $89.85 \pm 12.69$ & $-16.10 \pm 6.38$ & -11.28 & 0.000 \\
\hline Platelets & $181,900 \pm 52,934$ & $120,105 \pm 45,030$ & $61,795 \pm 25,839$ & -10.69 & 0.000 \\
\hline
\end{tabular}

PCR and Platelets were significantly decreased after treatment and P value was 0.000 for each, while ALT and AST were highly significantly increased with $P$ value 0.000 for each.

Table 4 shows frequency of HCV genotypes in studied groups. Genotype 4 was represented by 28/40 (70\%) cases in group I, and 4/20 (20\%) cases in group 2 (responders). This was followed by genotype 3b represented 
Table 4. Frequency of HCV genotypes in studied groups.

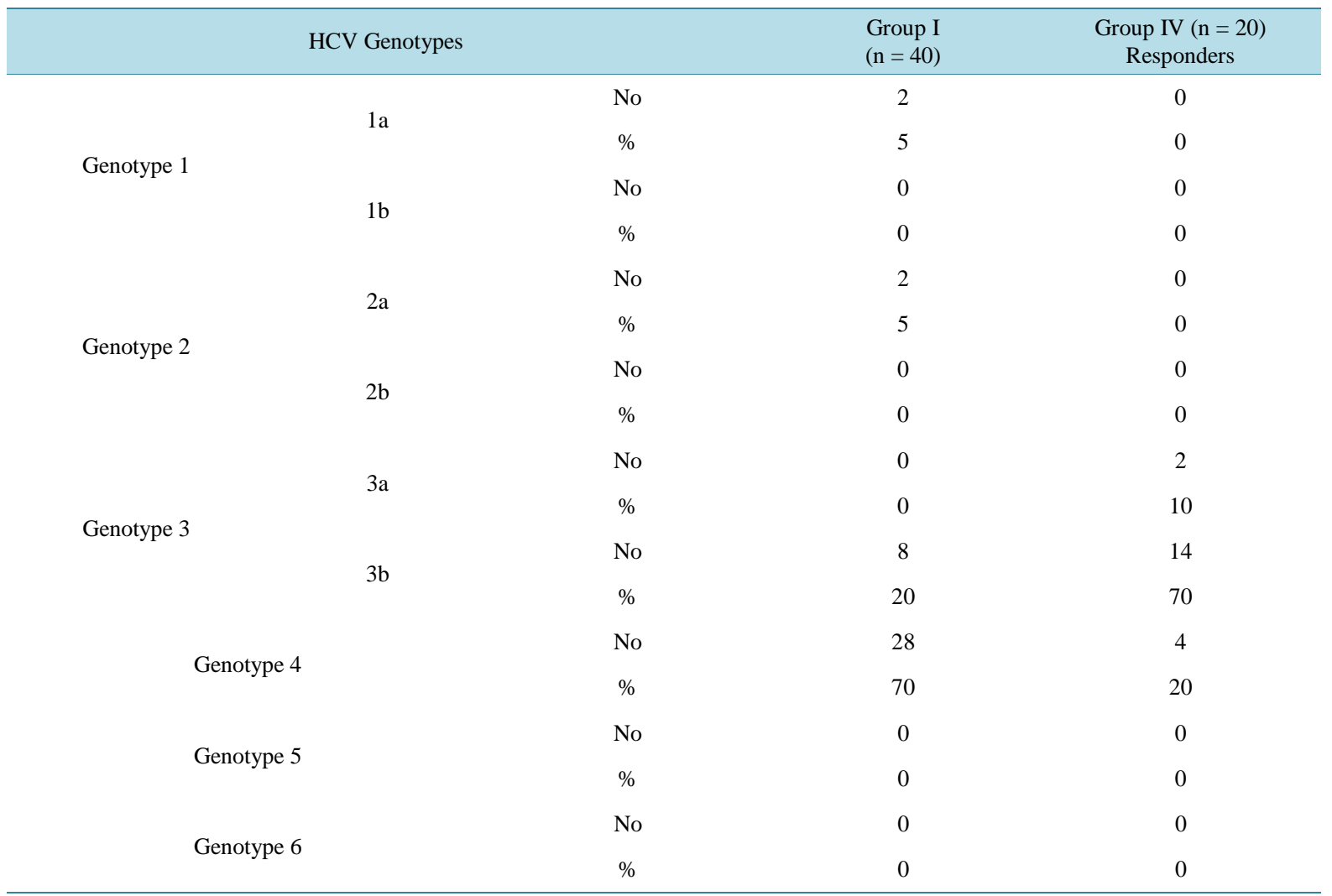

by $8 / 40$ (20\%) cases in group I, and 14/20 (70\%) cases in group 2 (responders). Genotype 3a that represented 2/20 (10\%) case in group 2 (responders), Genotype 5 and 6 were not found in any of the studied groups.

Table 5, on comparing patients in group In $=40$ (who developed resistance) to patients in group 2, no $=20$ (responders), it has been found that the most important risk factors for developing resistance are the increased viral load of HCV-RNA, AST, degree of fibrosis with P value 0.000 for each followed by degree of activity with $\mathrm{P}$ value 0.001.HCV-genotype as a risk factor was significantly higher among cases with genotype 1 and 4 and $\mathrm{P}$ value was 0.004 . This was followed by ALT and AFP as risk factors with P value 0.004 for each and age with $\mathrm{P}$ value 0.026 . However, regarding sex of the patients there was no significant difference between group I and II.

\section{Discussion}

HCV is a principal cause of chronic liver diseases including liver fibrosis, cirrhosis and hepatocellular carcinoma [10].

Viral genotypes and viral load are considered the most important predictors of response. The high replication rate of HCV is one of the factors that interfere with the probability of response [11].

This study included 60 patients with chronic HCV infection and subjected to PEG-INF plus RBV therapy. 40 (gp I) had developed resistance after 12 weeks; they were 28 males and 12 females. Four of them (10\%) were less than 40 years and 36 (90\%) were more than 40 years.

The comparison between laboratory tests profiles in group I $(n=40)$ before and after treatment. PCR and platelets were significantly decreased after treatment and P value was 0.000 for each, while ALT and AST were highly significantly increased with $\mathrm{P}$ value 0.000 for each (Table 3 ).

In similar studies, Alsaran et al., [12] compared responders to resistant patients, the higher ALT and AST levels were observed in resistant patients. While Balan et al., [13] reported that, HCV-infected patients receiving PEG-IFN/RBV therapy complaining of reductions in Hb, platelets, and WBCs, possibly due to bone marrow suppression. 
Table 5. Risk factors for resistance in group I patients $(n=40)$ versus responders $(n=20)$ to IFN therapy plus RBV.

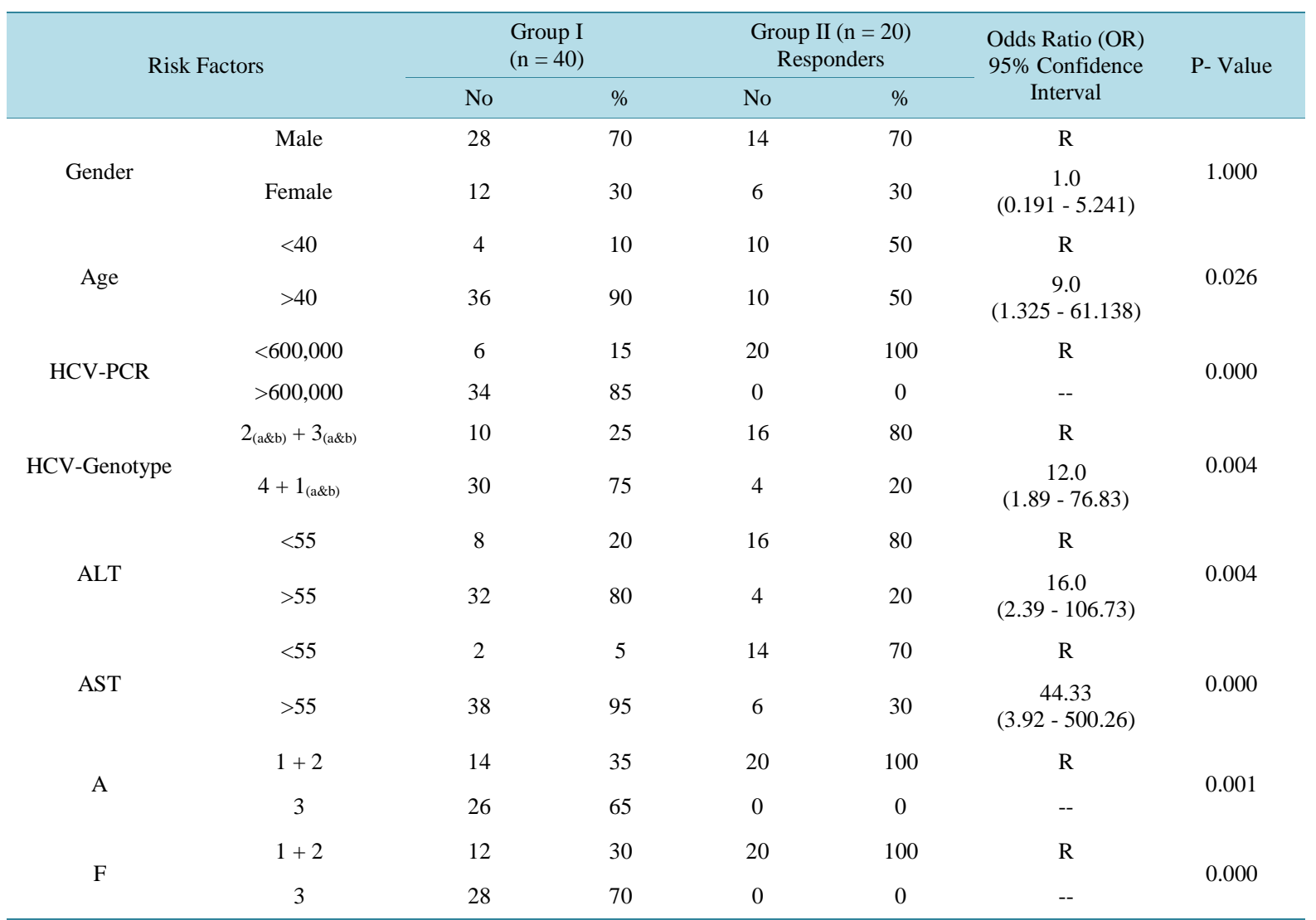

In this study, we performed HCV genotyping for studied patients in order to find a possible correlation between response to treatment and specific genotype. In addition, we tried to discuss the studied clinical and laboratory parameters as risk factors for response versus resistance to IFN therapy plus RBV (Table 4 and Table 5).

Frequency of different HCV-genotypes is shown in Table 4 Genotype 4 was the most prevalent representing (70\%) cases in group I and (20\%) cases in group II (responders). Followed by genotype 3b represented by (20\%) cases in group I and 14/20 (70\%) cases in group II. Then HCV genotypes 1a plus 2a was found in (5\%) case in group I. Genotypes1b, 2b, 5 and 6 were not found in any of the studied patients.

Lavanchy, [14] proved that Egypt has the highest HCV prevalence in the world. Although HCV genotype 4 remains the predominant genotype in Egypt; Saleh et al., [15] revealed the presence of HCV genotype 3 in a significant percentage of Egyptian patients.

Several studies have shown that both HCV genotype 2 and 3 are associated with a better response to IFN therapy plus RBV than HCV genotype 1 and 4. HCV genotype 5 was considered to be sensitive to treatment [16]. HCV genotype 6 has a better response than genotype 1 [17].

So, HCV genotype should be determined before treatment is started. The HCV genotype drives the treatment indication. Patients infected with HCV genotypes other than 1 should be treated with pegylated interferon (PEGIFN) and RBV only. Patients infected with HCV genotype 1 should receive the triple combination of PEG-IFN, RBV and a protease inhibitor (either telaprevir or boceprevir) [18] [19].

HCV genotyping is performed by several molecular techniques, such as sequencing of cloned genome, hybridization and Restriction Fragment Length Polymorphism (RFLP). The gold standard method for HCV genotyping is sequencing but this technique is expensive and requires many equipments and facilities, therefore not formidable in most regional laboratories. Contrary, RFLP is a sensitive and cost-effective method especially when a numerous amount of samples need to be genotyped. In RFLP, part of 5'-UTR is amplified by PCR and the amplicon is digested by restriction enzymes. The genotype of the HCV is determined based on the pattern of the fragments following digestion [20]. 
Regarding degree of activity as a risk factor for response to treatment, degree of activity (A1 + A2) were found in (35\%) patients in non responder group (group I) and (100\%) patients in responders group. (A3) was represented by (65\%) of patient in non responder group and was not represented by any patient in responders group (0\%) (Table 4$)$.

Pockros et al., [21] and Jármay et al., [22] stated that; there was a positive correlation between the degree of virological response and improvements in METAVIR activity and fibrosis, and an inverse correlation with worsening activity and fibrosis. Suggesting that, in patients with chronic hepatitis $C$ who were treated with interferon-based therapies, histological benefits might be observed even in the absence of response to treatment.

On comparing patients in group I to patients in group II, it has been found that the most important risk factors for developing resistance are the increased HCV viral load, AST level and degree of fibrosis with $\mathrm{P}$ value 0.000 for each followed by degree of activity with P value 0.001 (Table 4). HCV-genotype and ALT as risk factors showed $\mathrm{P}$ value 0.004 for both.

However, regarding sex of the patients, there was no significant difference between group I and II.

On the contrary, Nachnani et al. [23] mentioned that absence of early viral response; AST and ALT levels were independent predictors of absence of response to treatment in patients with chronic HCV infection receiving PEG-IFN and RBV combination treatment.

In a study by Hung et al. [24], he stated that HCV genotype remained the strongest predictor of treatment response [25] [26].

In conclusion: the most frequent HCV genotype in resistant group were genotype I and IV, while in responder patient were genotype $2 \& 3$. The most important risk factors in this study were viral load, HCV genotype, degree of activity and fibrosis.

\section{References}

[1] Strader, D.B., Wright, T., Thomas, D.L. and Seeff, L.B. (2004) American Association for the Study of Liver Diseases. Diagnosis, Management, and Treatment of Hepatitis C. Hepatology, 39, 1147-1171. http://dx.doi.org/10.1002/hep.20119

[2] Imazeki, F., Yokosuka, O., Fukai, K., et al. (2003) Favorable Prognosis of Chronic Hepatitis C after Interferon Therapy by Long-Term Cohort Study. Hepatology, 38, 493-502. http://dx.doi.org/10.1053/jhep.2003.50329

[3] Chevaliez, S. and Pawlotsky, J.M. (2006) Hepatitis C Virus Serologic and Virologic Testes and Clinical Diagnosis of HCV-Related Liver Disease. International Journal of Medical Sciences, 3, 35-40. http://dx.doi.org/10.7150/ijms.3.35

[4] National Institutes of Health Consensus Development Conference Statement (2002) Management of Hepatitis C. Hepatology, 36, S3-S20.

[5] Houck, D.R. (2006) Preclinical Evaluation of SCY-635, a Cyclophilin Inhibitor with Potent Anti-HCV Activity. Hepatology, 44, S534.

[6] Farci, P. and Purcell, R.H. (2000) Clinical Significance of Hepatitis C Virus Genotypes and Quasispecies. Seminars in Liver Disease, 20, 10-126.

[7] Bedossa, P. and Poynard, T. (1996) An Algorithm for the Grading of Activity in Chronic Hepatitis C. The METAVIR Cooperative Study Group. Hepatology, 24, 289-293. http://dx.doi.org/10.1002/hep.510240201

[8] Kaplan, M.M. and Bonis, P.A. (2009) Histologic Scoring Systems for Chronic Liver Disease.

[9] Pohjanpelto, P., Lappalainen, M., Widell, A., Asikainen, K. and Paunio, M. (1996) Hepatitis C Genotypes in Finland Determined by RFLP. Clinical and Diagnostic Virology, 7, 7-16. http://dx.doi.org/10.1016/S0928-0197(96)00242-5

[10] Simmonds, P. (2004) Genetic Diversity and Evolution of Hepatitis C Virus-15 Years on. Journal of General Virology, 85, 3173-3188. http://dx.doi.org/10.1099/vir.0.80401-0

[11] Levrero, M. (2003) Cellular Mechanisms of Resistance to INFS. In: Ferenci, P., Ed., EASL Postgraduate Course, Istanbul, Turkey, Kenes International, Geneva.

[12] Alsaran, K., Sabry, A. and Shaheen, N. (2011) Pegylated Interferon Alpha-2a for Treatment of Chronic HCV Infection in Hemodialysis Patients: A Single Saudi Center Experience. International Urology and Nephrology, 43, 865-873. http://dx.doi.org/10.1007/s11255-010-9756-1

[13] Balan, V., Schwartz, D., Wu, G.Y., Muir, A.J., Ghalib, R., Jackson, J., Keeffe, E.B., Rossaro, L., Burnett, A., Goon, B.L., Bowers, P.J. and Leitz, G.J. (2005) Erythropoietic Response to Anemia in Chronic Hepatitis C Patients Receiving Combination Pegylated Interferon/Ribavirin Erythropoietic Response to IFN/RBV Therapy. The American Journal of Gastroenterology, 100, 299-307. http://dx.doi.org/10.1111/j.1572-0241.2005.40757.x 
[14] Lavanchy, D. (2011) Evolving Epidemiology of Hepatitis C Virus. Clinical Microbiology and Infection, 17, $107-115$. http://dx.doi.org/10.1111/j.1469-0691.2010.03432.x

[15] Saleh, O., Baiomy, A.A., El-Desouky, A., Zaghloul, H., El-Arman, M., Dahab, G.M. and Abdel-Rahman, M.S. (2013) Hepatitis C Virus Genotype Distribution in Egyptian Diabetic Patients: A Preliminary Study. Arab Journal of Gastroenterology, 14, 14-19. http://dx.doi.org/10.1016/j.ajg.2013.01.005

[16] Abravanel, F.L., Sauné1, K.S., Barange, K., Alric, L., Moreau, J., Desmorat, P., Vinel, J.P. and Izopet, J. (2004) Hepatitis C Virus Genotype 5: Epidemiological Characteristics and Sensitivity to Combination Therapy with Interferon- $\alpha$ Plus Ribavirin. The Journal of Infectious Diseases, 189, 1397-1400. http://dx.doi.org/10.1086/382544

[17] Hui, C.K., Yuen, M.F., Sablon, E., Chan, A.O., Wong, B.C. and Lai, C.L. (2003) Interferon and Ribavirin Therapy for Chronic Hepatitis C Virus Genotype 6: A Comparison with Genotype 1. The Journal of Infectious Diseases, 187, 10711074. http://dx.doi.org/10.1086/368217

[18] Chevaliez, S. (2013) New Markers for Diagnosis and Management of Chronic Hepatitis C Virus Infection. Annals of Gastroenterology, 26, 98-99.

[19] DeLeuw, P., Sarraz, C. and Zeuzem, S. (2011) How to Use Virological Tools for the Optimal Management of Chronic Hepatitis C. Liver International, 31, 3-12. http://dx.doi.org/10.1111/j.1478-3231.2010.02398.x

[20] Hamidi, F.M., Samarbaf, Z.A., Makvandi, M. and Hajiani, E. (2009) Determination of HCV Genotypes among Chronic Hepatic Patients in Ahvaz. Iranian Journal of Virology, 3, 12-16.

[21] Pockros, P.J., Hamze, F.M., Martin, P., Lentz, E., Zhou, X., Govindarajan, S. and Lok, A.S. (2010) Histologic Outcomes in Hepatitis C-Infected Patients with Varying Degrees of Virologic Response to Interferon-Based Treatments. Hepatology, 52, 1193-1200. http://dx.doi.org/10.1002/hep.23809

[22] Jármay, K., Lonovics, J. and Schaff, Z. (2003) Clinicopathologic Observations on Chronic Hepatitis C Therapy with Interferon-Alpha. Orvosi Hetilap, 144, 1325-1330.

[23] Nachnani, J.S., Gidwani, R., Sadeddin, E., Clarkston, W.K., Fiorella, R. and Alba, L.M. (2007) Clinical Pathological Predictors to Predict Sustained Viral Response Rates in Patients with Chronic Hepatitis C Infection. Indian Journal of Gastroenterology, 26, 279-282.

[24] Hung, C.H., Lee, C.M., Lu, S.N., Wang, J.H., Chen, C.H., Hu, T.H., Kee, K.M., Chang, K.C., Tseng, P.L., Yen, Y.H. and Changchien, C.S. (2006) Anemia Associated with Antiviral Therapy in Chronic Hepatitis C: Incidence, Risk Factors, and Impact on Treatment Response. Liver International, 26, 1079-1086. http://dx.doi.org/10.1111/j.1478-3231.2006.01354.x

[25] Zeuzem, S., Feinman, S.V., Rasenack, J., et al. (2000) Peginterferon Alfa-2a in Patients with Chronic Hepatitis C. The New England Journal of Medicine, 343, 1666-1672. http://dx.doi.org/10.1056/NEJM200012073432301

[26] Kau, A., Vermehren, J. and Sarrazin, C. (2008) Treatment Predictors of a Sustained Virologic Response in Hepatitis B and C. Journal of Hepatology, 49, 634-651. http://dx.doi.org/10.1016/j.jhep.2008.07.013 